\title{
Forord
}

\section{Af Henning Høirup.}

Grundtvig-Selskabet af 8. september 1947 udsender hermed den 20. årgang af Grundtvig-Studier. I sin tid, da vi henvendte os til Gyldendal om udgivelsen af første årgang i i 948, spåede forlaget ud fra sine erfaringer, at publikationen kun kunne gennemføres i en kort årrække; dels var markedet for lærde litterære årbøger ringe, dels var det næppe sandsynligt, at tilstrækkeligt materiale vedblivende ville fremkomme.

Glædeligvis er det lykkedes uden afbrydelse at gennemføre Grundtvig-Studier som et forum for forskningens mange områder, og det har aldrig været redaktionens vanskelighed at skaffe stof, men at skaffe plads til de modtagne afhandlinger.

Den Io. årgang af Grundtvig-Studier - 1957 - indledtes med en skildring af undertegnede om »Grundtvig-Selskabets tilblivelse og virksomhed i dets første tiår«. Nærværende 20. årgang bringer ikke en tilsvarende oversigt over Selskabets historie i det andet tiår 1958I967, idet Grundtvig-Studier som bekendt fra og med r958 løbende har meddelt årsoversigter over Selskabets virksomhed, bygget på formandens beretninger ved årsmøderne. Derimod har vi fundet det rigtigt at lade udarbejde indholdsoversigter over de sidste ro årgange, idet det har vist sig at de nyttige og tidsbesparende indholdsoversigter og registre over Grundtvig-Studier 1948-1957, som bragtes ved bibliotekar Hans Eriksen i årgang 1957, har været meget påskønnende.

Jeg benytter lejligheden til at takke redaktøren gennem hele denne periode professor, dr. phil. Gustav Albeck for det meget store arbejde, som er nedlagt i årbogens tilrettelæggelse. At det har båret frugt viser den stærke benyttelse af årbogens afhandlinger i hele den omfattende litteratur om Grundtvig, som er fremkommet i dette tidsrum.

Henning Høirup. 